\title{
HŐKEZELÉSI FOLYAMATOK ÖSSZEHANGOLÁSA EXCEL VBA SZOLGÁLTATÁSOKKAL
}

\author{
Fabulya Zoltán
}

\begin{abstract}
Absztrakt: Konzervek hőkezelési folyamatainak összehangolása során az egyes folyamatok kezdési időpontjának késleltetésével elkerülhetjük a gőz-, és a vízfelhasználási csúcsokat. Az Excel Visual Basic for Application szolgáltatása megfelelő keretet biztosít arra, hogy felhasználóbarát kezelöfelületet alakítsunk ki, mellyel akár egy egyedi felhasználói program megjelenését és kezelésének kényelmét biztosíthatjuk. Így az informatikában járatlanok is könnyen használható, programként müködő alkalmazással dolgozhatnak. Parancsgombokra klikkelve hangolhatjuk össze a párhuzamosan zajló folyamatokat, miközben diagramokon követhetjük a gőz-, és vízfelhasználás alakulását.

Abstract: By synchronizing the heat treatment processes of the canned food, delaying the start time of each process can prevent vapor and water consumption peaks. Excel Visual Basic for Application offers the suitable framework for creating a user-friendly interface that can provide the appearance and convenience of a unique application program. Thus, inexperienced users can work with an easyto-use application which operates as a program. The parallel processes can be synchronized by clicking on command buttons, while the steam and water consumption can be followed on diagrams.
\end{abstract}

Kulcsszavak: hőkezelés, ütemezés, programozás, Excel VBA

Keywords: heat treatment, synchronizing, programming, Excel VBA

\section{Bevezetés}

A táblázatkezelő programok használata nagymértékben felgyorsítja az adatváltozások hatására szükséges újraszámítások elvégzését. Konzervek hőkezelési folyamatainak összehangolása során így lehetőségünk van az egyes folyamatok kezdési időpontjának késleltetésével arra, hogy a göz-, és a vízfelhasználási csúcsokat figyelemmel kísérhessük akár diagramok segítségével vizuálisan is (Fabulya-Nagy, 2007)). Az Excel Visual Basic for Application megfelelö keretet biztosít arra is, hogy felhasználóbarát kezelöfelületet alakíthassunk ki (ChenRamaswamy, 2007), mellyel akár egy egyedi felhasználói program megjelenését és kezelésének kényelmét biztosíthatjuk (Fabulya, 2007; Fabulya, 2008). Így az informatikában járatlanok is könnyen használható, programként müködő alkalmazással dolgozhatnak.

\section{Anyag és módszer}

A konzervek hőkezelése során termékenként eltérö elöírás tartalmazza a folyamat három fázisának:

- felfütés,

- höntartás,

- lehütés

időtartamát, valamint az elérendő hömérsékletet. Ezek betartását a hőkezelö berendezés, az autokláv, automatikusan elvégzi. Több berendezésben párhuzamosan történik a kezelés, melyek gőzt használnak fel a felfütés és höntartás során, míg vizet 
a hütéskor. Ahhoz, hogy kalkulálni tudjuk a pillanatnyi összegzett gőz- és vízfogyasztást egy nap folyamán, ismernünk kell, hogy egy-egy folyamat esetén ez hogyan alakul az idő függvényében (Bhowmik et al., 1985). Így a folyamatok tervezett indítási időpontja alapján láthatjuk, hogy mikor fognak gőz-, illetve vízfelhasználási csúcsok megjelenni, melyek akár a kapacitást is meghaladhatják. A kapacitás feletti igények elkerülése miatt fontos összehangolni, ütemezni a párhuzamosan zajló folyamatokat, melyhez az Excel táblázatkezelő program biztosítja:

- a számítások automatizálását,

- az eredmények megjelenítését grafikonon,

- az ütemezés felhasználóbarát támogatását VBA (Visual Basic for Application) szolgáltatásokkal.

Az eltérő időtartamú kezelések gőz- és vízfelhasználásának alakulása az idő függvényében méréssel adódott, de azonos jelleggel. Így egyetlen normalizált jelleggörbével ábrázolható (1. ábra).

\section{1. ábra: A gőzfelhasználás normalizált jelleggörbéje}

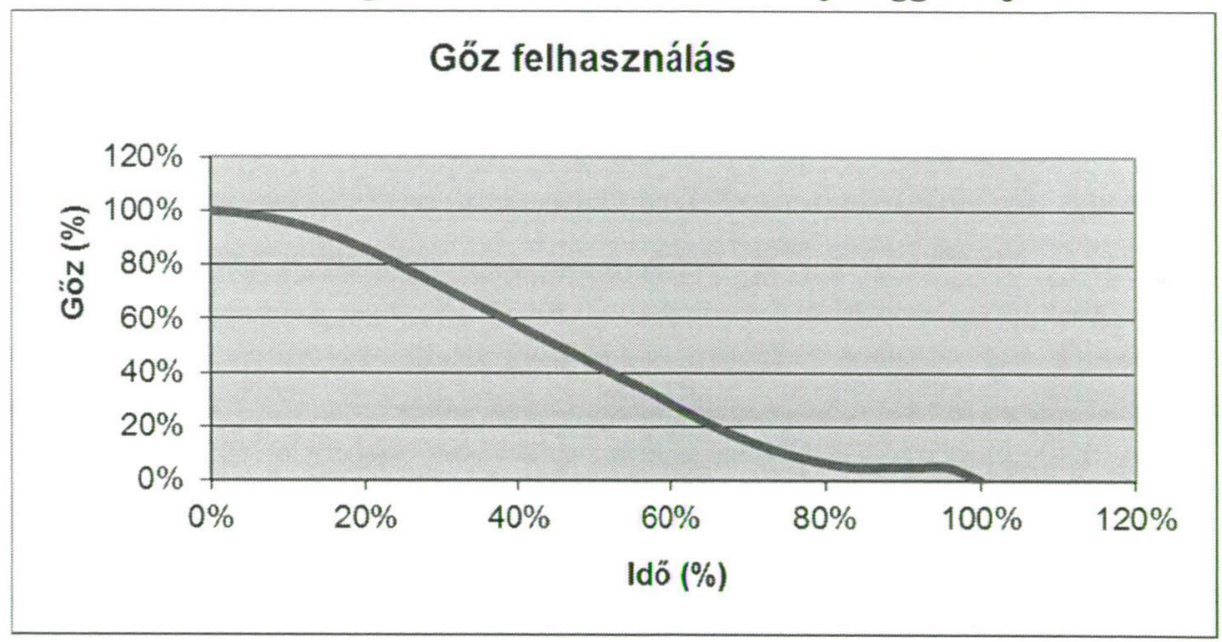

Forrás: Fabulya (2007)

A normalizálás alatt azt kell érteni, hogy a gőzfelhasználási fázis teljes időtartamát, valamint a maximális gőz tömegáramot $100 \%$-nak tekintjük. Így az időtartam és a maximális érték alapján bármely termékhez megkaphatjuk a gőzigényt minden időpillanatban. Ugyanilyen normalizálás alapján a vízigény is adódik.

A kapacitások (2. ábra) szintén mérés alapján ismertek. 
2. ábra: A kapacitások az idő függvényében egy nap során

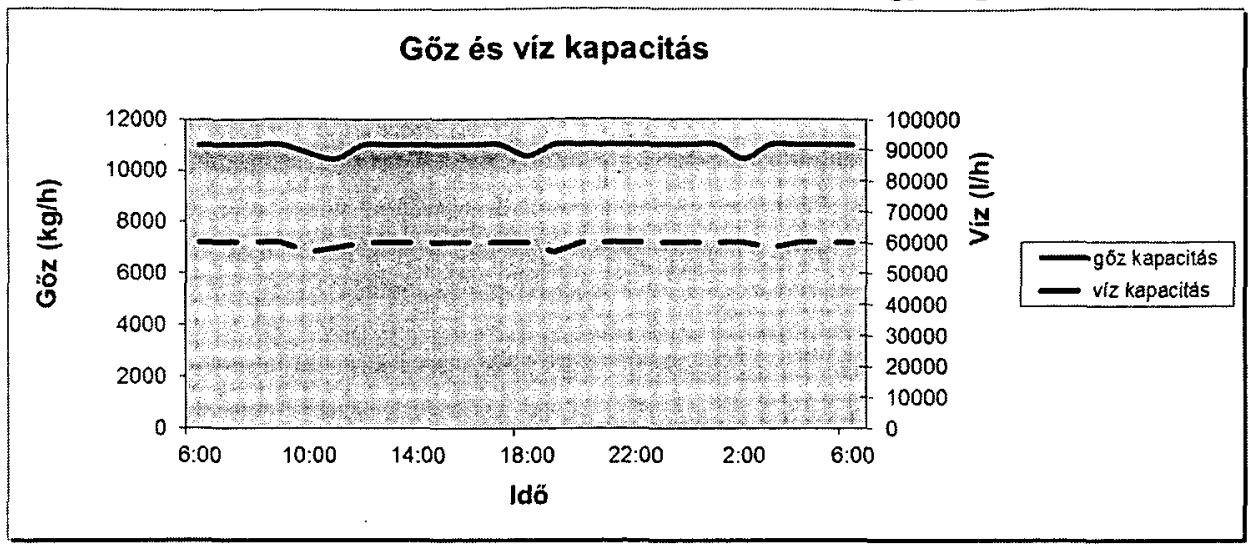

Forrás: Fabulya (2007)

\section{Eredmények és értékelésük}

Szerepük alapján több munkalapra volt szükség:

- Termék

- Fütés

- Hütés

- Kapacitás

- Számítás

- Ütemezés

A Termék munkalapon tárolódnak az egyes termékek adatai. A felhasználóbarát hozzáférést az Excel ürlap szolgáltatása biztosítja. Az ürlapot a termék adataival a 3. ábra mutatja.

\section{3. ábra: Termék adatainak ürlapja}

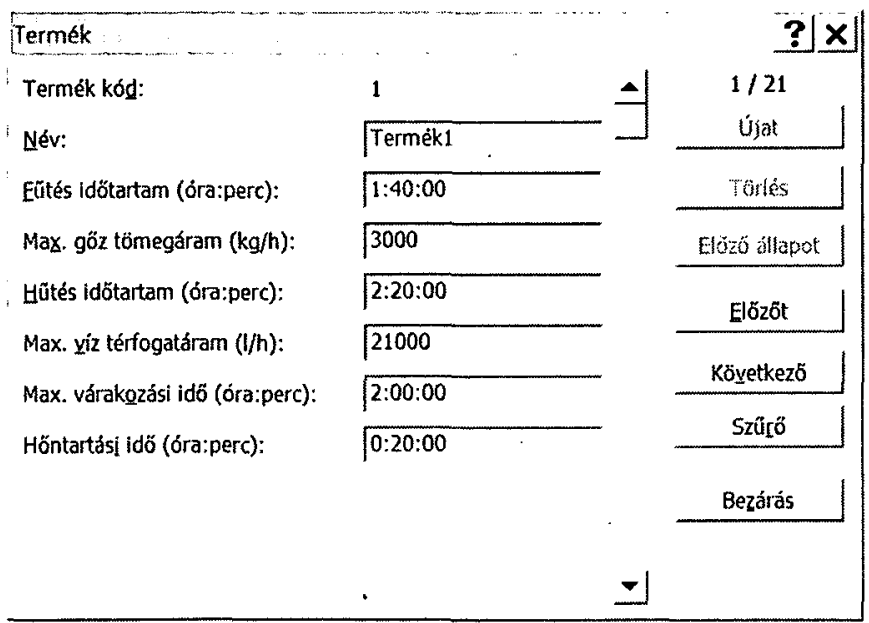

Forrás: A szerző saját szerkesztése. 


\section{2. ábra: A kapacitások az idő függvényében egy nap során}

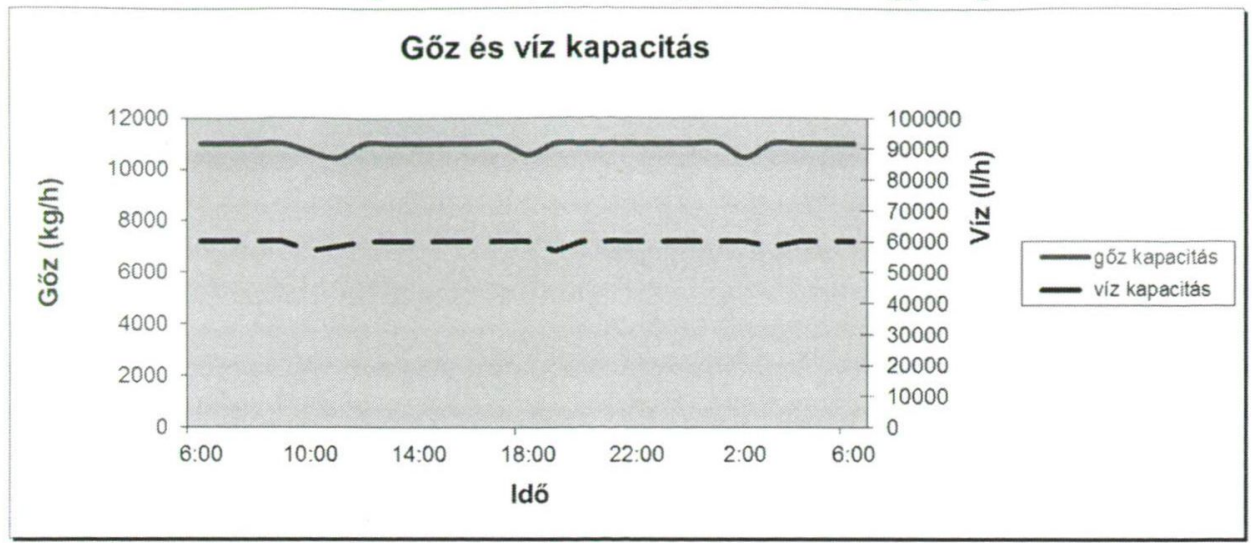

Forrás: Fabulya (2007)

\section{Eredmények és értékelésük}

Szerepük alapján több munkalapra volt szükség:

- Termék

- Fütés

- Hütés

- Kapacitás

- Számítás

- Ütemezés

A Termék munkalapon tárolódnak az egyes termékek adatai. A felhasználóbarát hozzáférést az Excel ürlap szolgáltatása biztosítja. Az ürlapot a termék adataival a 3. ábra mutatja.

\section{3. ábra: Termék adatainak ürlapja}

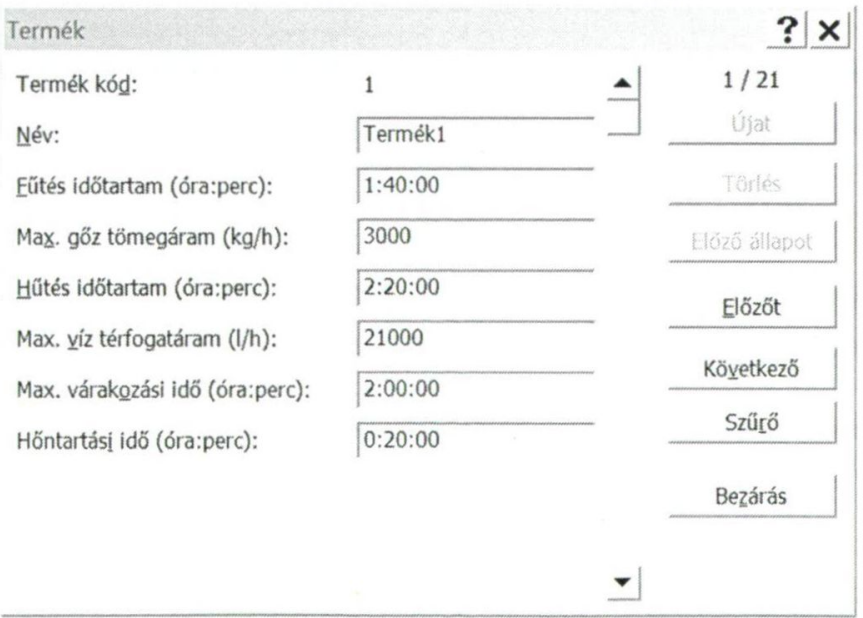

Forrás: A szerző saját szerkesztése. 
A Fứtés és Hütés munkalapokon tárolódnak a jelleggörbék adatai, míg a gőzés víz kapacitás adatai a Kapacitás munkalapon. A Számítás munkalapon állítjuk be, hogy egy nap folyamán szükséges hőkezelési folyamatok adatait:

- Termék kód

- Legkorábbi kezdési idő

- Várakozási idő

- Még ütemezhető (1: igen/0: nem)

Az egyes folyamatok adatai egymás melletti oszlopokban találhatók. Ezekben az oszlopokban számítódik ki, hogy a nap 10 perces időintervallumokra bontott szakaszaiban mekkora gőz- illetve vízfogyasztást okoz a folyamat. Ezek összesítése egy újabb oszlopban adódik. Tehát a Számítás munkalapon automatikusan újraszámítódik minden eredmény, amikor a várakozási időt módosítjuk a hőkezelési folyamatok összehangolása, ütemezése során.

\subsection{Felhasználóbarát felület kialakítása}

A folyamatok összehangolása manuálisan történik a folyamatok kezdési időpontjának beállításával. Ezt a várakozási idő értékének módosításával tehetjük meg 10 perces lépésekkel. Viszont a módosítás hatását, a gőz- és vízfogyasztás időbeli változását, elsősorban a kapacitás feletti mérték változását mutatnia kell a kezelö felületnek. Ezt két módon is biztosítja a felület:

- Egy-egy számértékkel a gőzre és vízre összegzéssel adódó túllépésekből.

- Diagramon (4. ábra) megjelenítve 10 perces felbontásban a folyamatok összegzett igényét a kapacitással együtt.

\section{4. ábra: A gőz felhasználás és kapacitás az idő függvényében egy nap során}

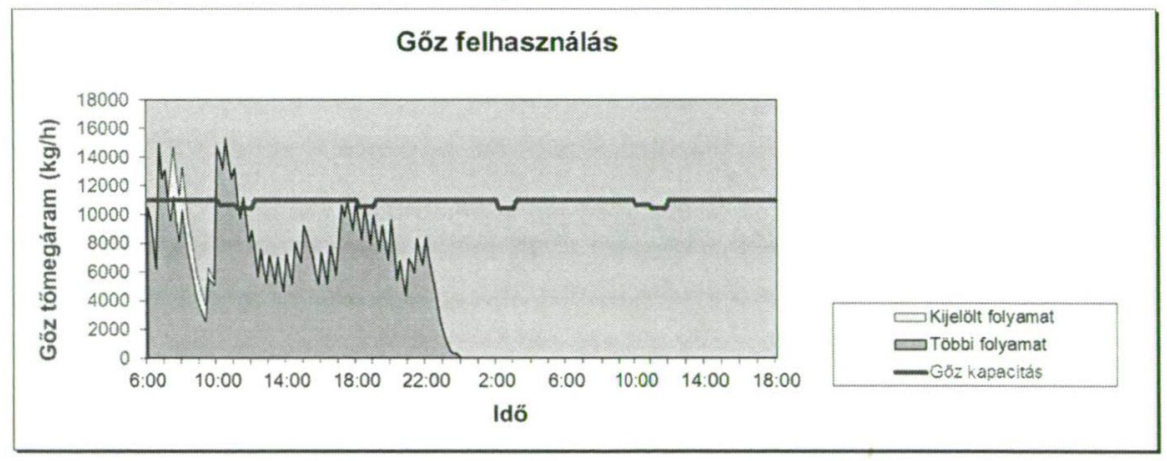

Forrás: A szerző saját szerkesztése.

A kezelőfelületnek csak azt kell biztosítania, hogy az egyes folyamatok várakozási idejét tudja a felhasználó változtatni 10 perces lépésekben. Ez az érték tárolódik minden folyamat esetén egy-egy cellában, így akár ott is elvégezhető a módosítás, de másik munkalapon. Ezért ekkor nem tudná követni egyszerủen a felhasználó a módosítás hatását. Ráadásul az adat begépelése további problémákat is okozhat: 


\subsubsection{A parancsgombok kialakítása}

A gombokhoz egy-egy VBA szubrutin tartozik, melyek akkor hajtódnak végre, amikor rájuk klikkelünk. Feladatuk, hogy egy-egy cella értékét ellenőrzött módon változtassák meg. Az 1. programon látható a kijelölt folyamat sorszámát tároló cella eggyel csökkentését elvégző eljárás VBA kódja.

\section{1. program: Az előző folyamat kijelölésének VBA eljárása}

Private Sub PrevProc_Click()

highlighted $=$ Worksheets ("Ütemezés"). Cells $(22,9)$

If highlighted $>1$ Then

highlighted $=$ highlighted -1

Worksheets ("Ütemezés"). Cells (22, 9) = highlighted

End If

End Sub

Forrás: A szerző saját szerkesztése.

Az eljárás első utasításában kiolvassa az Ütemezés munkalap adott cellájából a kijelölt folyamat sorszámát, melyet a high lighted változóban tárol. Csak akkor csökkenti a változó értékét és helyezi vissza az új értéket a cellába, ha ez megtehető. Ekkor a diagramon is ennek megfelelően változik az eltérő színnel kijelölt rész.

A következő folyamat kijelölését ehhez hasonlóan lehetett kialakítani.

2. program: Az kijelölt folyamat várakozási idejét növelő VBA eljárás Private Sub WaitPlus_Click()

highlighted = Worksheets ("Ütemezés"). Cells $(22,9)$

scheduled $=$ Worksheets ("Ütemezés"). $\operatorname{Cells~}(26,9)$

waitTime $=$ Worksheets ("Számítás"). Cells $(4,14$ thighlighted)

limit $=$ Worksheets ("Ütemezés"). Cells (24, 9)

If scheduled $=1$ Then

If waitTime $+1 / 24 / 6<=$ limit Then

waitTime $=$ waitTime $+1 / 24 / 6$

Worksheets ("Számítás") . Cells (4,14+highlighted)=waitTime

Else

waitTime $=$ limit

Worksheets ("Számítás") .Cells (4, 14+highlighted)=waitTime

End If

End If

End Sub

Forrás: A szerző saját szerkesztése. 
A 2. programon látható a kijelölt folyamat várakozási idejét tároló cella 10 perccel növelését elvégző eljárás VBA kódja.

A program első 4 utasítása kiolvassa a szükséges adatokat cellákból, és egy-egy változóban tárolja. Ezek a következők:

- kijelölt folyamat sorszáma,

- még ütemezhető,

- várakozási idő,

- maximális várakozási idő.

Csak akkor növeli a várakozási idöt 10 perccel (1/24/6: 1 nap 24-ed részének hatoda), ha a folyamat még ütemezhető és ezzel nem haladjuk meg a maximális várakozási időt. A növelt értéket visszaírva a cellába a diagramon is követhetjük a változást, valamint a túllépés értéke is változik.

A várakozási idő csökkentése is ehhez hasonló módon történik.

\section{Következtetések, összegzés}

Az Excel táblázatkezelő program használatával az adatváltozásokból eredő újraszámítások automatikusan végrehajtódnak a munkalapok celláiban. Ez közismert, és jellemzően ezért is használjuk előszeretettel a programot. Viszont az Excel fejlesztőeszközeit használva lehetöségünk van felhasználóbarát kezelőfelület kialakítására. Ehhez sokszor elegendő csak olyan minimális programozási ismeret, melyekkel egy-egy cella értékének megváltozását valósítjuk meg feltételektől függő módon. Ehhez úgy kell kialakítanunk a munkalapokat, hogy a szükséges funkciók cellák értékének módosításával kezelhetők legyenek. Erre láttuk példaként, hogy egy összetettebb feladat is hatékonyan, egyedi felhasználói program kezeléséhez hasonlóan alakítható ki.

\section{Irodalomjegyzék}

Bhowmik, S. R., Vichnevetsky, R., Hayakawa, K. I. (1985): Mathematical model to estimate steam consumption in vertical still retort for thermal processing of canned foods. Lebensmittelwissenschaft und Technologie, 18 (1): 15-23.

Chen, C. R., Ramaswamy, H. S. (2007): Visual Basics computer simulation package for thermal process calculations. Chemical Engineering and Processing, 46 (7): 603-613.

Fabulya, Z. (2007): Autoklávos hőkezelés szimulációja élelmiszeripari vállalatok energia költségének optimalizálására. In: Acta Agraria Kaposváriensis 11 (2): 125-134.

Fabulya, Z. (2008): Autoklávos hőkezelés számítógépes modellezése, erőforrásainak optimális felhasználása. Agrár- és Vidékfejlesztési Szemle 3 (1): 71. Multifunkcionális Mezögazdaság nemzetközi tudományos konferencia, Hódmezővásárhely, 2008.04.24. SZTE Mezőgazdasági Kar, Hódmezővásárhely. Proceedings in CD: SZTE_2008_04/pdf/062_Fabulya.pdf

Fabulya, Z., Nagy, M. (2007): Developing managerial decision preparing system for food industry enterprises using heat treating autoclave. In: Proceedings of the 6th Biennal Conference of European Federation of IT in Agriculture, Glasgow, 2007.07.02-05., Caledonian University, Glasgow. Proceedings in CD-ROM: EFITA Proceeding CD/monday/1400/business_themedss_applications /fabulya_zoltan_20070331151402.pdf 